\title{
IMPACT OF PUBLIC DEBT SUSTAINABILITY ON FISCAL POLICY IN CROATIA*
}

\author{
Hrvoje ŠIMOVIĆ \\ (Received: 14 September 2017; revision received: 2 January 2018; \\ accepted: 8 January 2018)
}

This paper analyses the impact of public debt level and its (un)sustainability on fiscal policy in Croatia in the 2001-2015 period. A switching regression approach is used to distinguish different regimes when government spending, i.e. fiscal policy has more or less impact on economic growth during different cycles. In the second part, the structural VAR model is used to analyse the dynamic effects of government spending on domestic demand in Croatia. To observe the public debt effects on a fiscal policy, a "closed" model is compared with an "extended" model which includes a debtto-GDP indicator. Results show a negative impact of recession on public debt sustainability and confirm the main thesis that public debt level significantly affects and reduces the effectiveness of fiscal policy in Croatia.

Keywords: public debt, fiscal policy, Croatia

JEL classification indices: H68, H50, E62

*This work has been supported by the Croatian Science Foundation under project "Public Finance Sustainability on the Path to the Monetary Union - PuFiSuMU" No. IP-2016-06-4609.

Hrvoje Šimović, Associate Professor at the Faculty of Economics \& Business, University of Zagreb, Croatia. E-mail: hsimovic@efzg.hr 


\section{INTRODUCTION}

Croatia is one of the EU countries with the highest level of public debt. The main reason for such fiscal stance can be found in the extensive deficit financing, especially during the recent economic crisis. Croatia also had the longest recession period in EU that lasted for six consecutive years (2009-2014).

Public debt level is one of the major structural determinants of fiscal policy effectiveness. The dynamic effects of fiscal policy are usually measured by the size of fiscal multipliers. It is hard to directly assess the effects of public debt on the size of fiscal multipliers, but generally a higher debt level implies lower fiscal multipliers and lower fiscal policy effectiveness. The main mechanisms could be explained through the effects of risk assessment and confidence. High levels of public debt, especially in the recessionary environment, usually imply lower credit rating and higher risk spreads. These led to a higher level of interest rates on government debt, which directly and indirectly "spill over" into higher interest rates for private sector, thus discouraging private consumption and investment (Batini et al. 2014). Another channel goes through expectations as consumers and corporate sector can expect that the increased spending or the tax cuts at higher levels of public debt will eventually lead to higher taxes and/or spending cuts, they restrain from spending/investing (Ricardian equivalence). This determinant is often accounted for in the empirical literature, which generally confirms the theory (for example Ilzetzki et al. 2013; Hory 2016).

The main goal of this paper is to analyze the impact of public debt level and its (un)sustainability on the fiscal policy effectiveness in Croatia in the period 2001-2015. Induction of the gained results will confirm the thesis that public debt level significantly affects and reduces the effectiveness of fiscal policy in Croatia. In order to prove the thesis, the part following the introduction gives literature review that deals with public debt sustainability in Croatia, as well as the literature of similar researches and methodological approaches. In the third part, a simple fiscal sustainability analysis is conducted with empirical identification of the breakpoints and the changes in regime and it is suggested that the unsustainability of public debt in Croatia occurred in parallel with the recession, i.e. after 2008:Q4. The fourth part of the paper describes methodology of the empirical analysis and data. Results are discussed in the fifth section, while the last section presents the conclusion. 


\section{LITERATURE REVIEW}

Regarding the analysis of public debt sustainability, there are many papers which deal with certain types of public debt sustainability issues. The subject of public debt sustainability in Croatia was relatively present in earlier researches, but the interest for this topic has surprisingly subsided. Although, considering the amount of public debt, the excessive deficit procedures (EDP) and the macroeconomic imbalance procedure (MIP), it is more pertinent than ever.

Švaljek (1997) provides an overview of theoretical frameworks and standardized methods for evaluating the sustainability of public debt. Krznar (2002) provides the first empirical study on fiscal sustainability and using the cointegration analysis, the author comes to the conclusion that Croatia's fiscal policy is unsustainable. Babic et al. (2003) explore public debt sustainability on the grounds of standardised models and techniques, yet the analysis is not based on them, but on model simulation tools that analyse the debt sustainability considering projections of the basic macroeconomic variables. Mihaljek (2003) gives a detailed overview of debt indicators, the public debt sustainability models and compares Croatia with other Central and Eastern European (CEE) countries based on the available data where performances vary between indicators.

There are many other papers as well as many different approaches for measuring the public debt sustainability. Usually, the sustainability is observed through a broader framework called fiscal or public finances sustainability. Such analyses include three groups of indicators: fiscal vulnerability indicators, fiscal stability indicators and composite indicators. ${ }^{1}$ The main aggregate indicators of public debt, budget balance and interest payments will be observed as vulnerability indicators. ${ }^{2}$ The most common are static analyses of stability indicators (Mihaljek 2003; Sopek 2010; Šimović - Batur 2017), or certain dynamic analyses of fiscal sustainability (Babić et al. 2003; Sopek 2011), and analyses that involve composite indicators (Mihaljek 2009; Cota - Žigman 2011; Bajo - Primorac 2013; Šimović - Batur 2017). These papers alert to unsustainable projections of public debt level and fiscal policy in general.

Due to the fact that Croatia is a small open transition economy, the shocks of foreign origin impact its fiscal policy and public debt level. The external shock derived from the global financial crisis induced higher public debt in all EU

1 The most common composite (complex) indicators are credit rating, bond spreads and credit default swaps which contribute to observing current financial market assessment of the observed country.

2 Beside the aggregate indicators like public debt level, or liquidity indicators like interest payments level, vulnerability indicators include analysis of maturity and currency risk. 
members, especially the Eurozone periphery (Arghyrou - Kontonikas 2012). Regarding Croatian high euroisation and hard peg, such conclusion can be deducted also for Croatia (Šimović et al. 2014), and it may extend the negative impact on Croatia's public finance in the post-crisis period (Aizenman et al. 2013).

The empirical papers regarding impact of public debt on fiscal policy effectiveness are rather scarce for Croatia. Although there has been an obvious need for fiscal consolidation from the start of the global financial crisis and the recession later, there is a lack of literature that analyses and quantifies the short-term and the long-term effects of individual fiscal consolidation measures on the macroeconomic variables. Only one paper, using SVAR, is found where the structural characteristics like trade openness and public debt levels are used to analyse the fiscal multipliers in Croatia along with Slovenia and Serbia (Deskar-Škrbić Šimović 2017).

Following the empirical approach employed later in the paper, there are many papers that investigate the macroeconomic effects of fiscal policy using the SVAR methodology (panel VAR), and many of them observe public debt levels and debt dynamics as among the key determinants of fiscal policy effectiveness (for example see Afonso - Sousa 2009). Furthermore, the results imply that a higher public debt level decreases fiscal multipliers (Ilzetzki et al. 2013; Hory 2016; Deskar-Škrbić - Šimović 2017) or these are equal to zero in high-debt countries (Contreras Banco - Battelle 2014).

\section{PUBLIC DEBT AND FISCAL BALANCE DYNAMICS}

Further, the fiscal sustainability analyses in Croatia imply inadequate fiscal policy and public debt management (Šimović et al. 2014). The mentioned policies are proved to be particularly ineffective during the period of recession in Croatia, in which public debt has increased more than twice. In 2008 public debt was $39.6 \%$ of GDP and at the end of 2014 it amounted up to $86.5 \%$ of GDP. Figure 1 presents the public debt level in Croatia and the EU average in the 2001-2015 period and clearly shows the dynamic of Croatian public debt where Croatia overtakes EU average in its recession years.

In the period before the recession there was a decreasing trend in the public debt-to-GDP ratio, while at the same time the amount of nominal debt was slightly increasing. In the pre-crisis period Croatia implemented a strategy of public borrowing on domestic markets and this resulted in growth of internal debt more than the external. Since 2009, due to the influence of the global economic and the financial crisis, which generated decreased revenue and increased budget deficit, there has been a sudden increase in public debt and its part in GDP. The trend of 


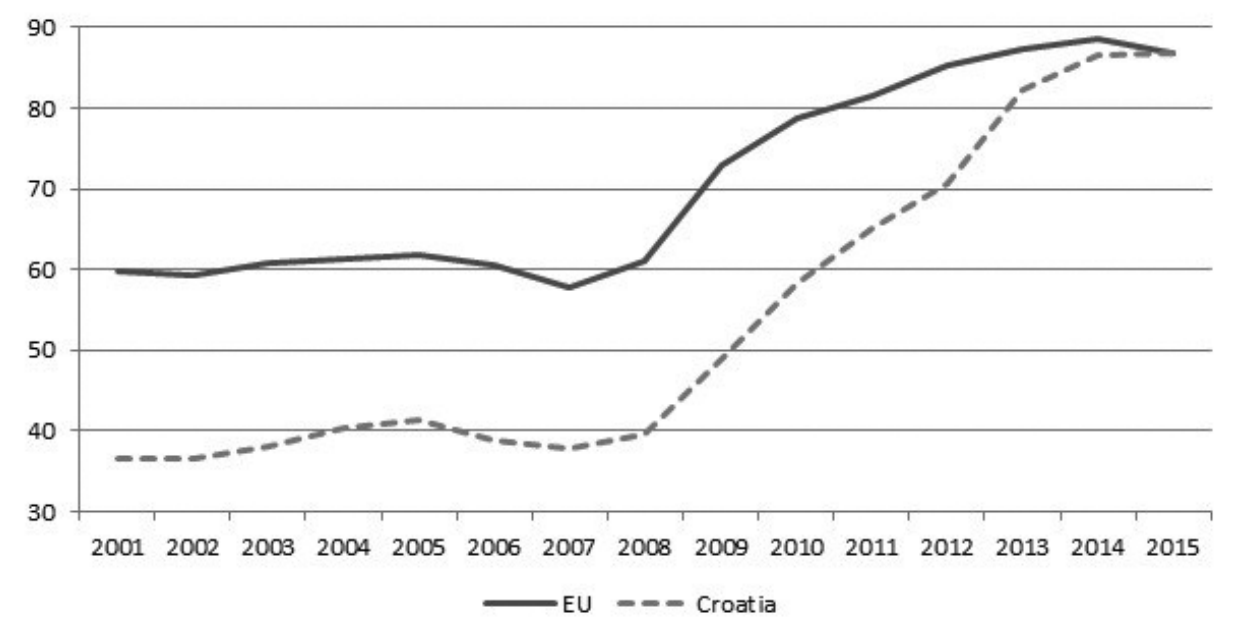

Figure 1. Public debt in Croatia and in the EU (\% of GDP)

Source: AMECO (2016).

the increasing public debt was influenced mostly by the growth of total general government deficit. Apart from the loss in tax revenues, the growth of budget deficit was a result of inadequate adjustment of public expenditure and raising interests on the public debt. Figure 2 presents the government budget balance in the period 2001-2015 and it is decomposed into primary balance and interest expenses.

The primary balance shows the connection between current expenditure and revenue, i.e. what would be the amount of budget deficit if interest expenses did not exist. Figure 2 clearly shows that in the period of recession the government did not adjust the primary balance. Moreover, due to increasing principal and global interest rates there has been a dramatic increase in interest expenses, which amounted to $3.56 \%$ of GDP by the end of 2015 .

Furthermore, the budget deficit and the public debt growth were largely contributed by the change in interest rates, the so called snowball effect. The effect arises from the interaction between differential cost of refinancing debt and economic growth on one hand, and the level of public debt on the other hand. Considering that in the time of recession the cost of (re)financing debt was rising, the level of public debt would have been unsustainable even if the government had not generated (primary) budget deficit. In other words, public debt would have increased due to rising interest rates even if the government had been able to carry out fiscal adjustment and decrease budget deficit. 


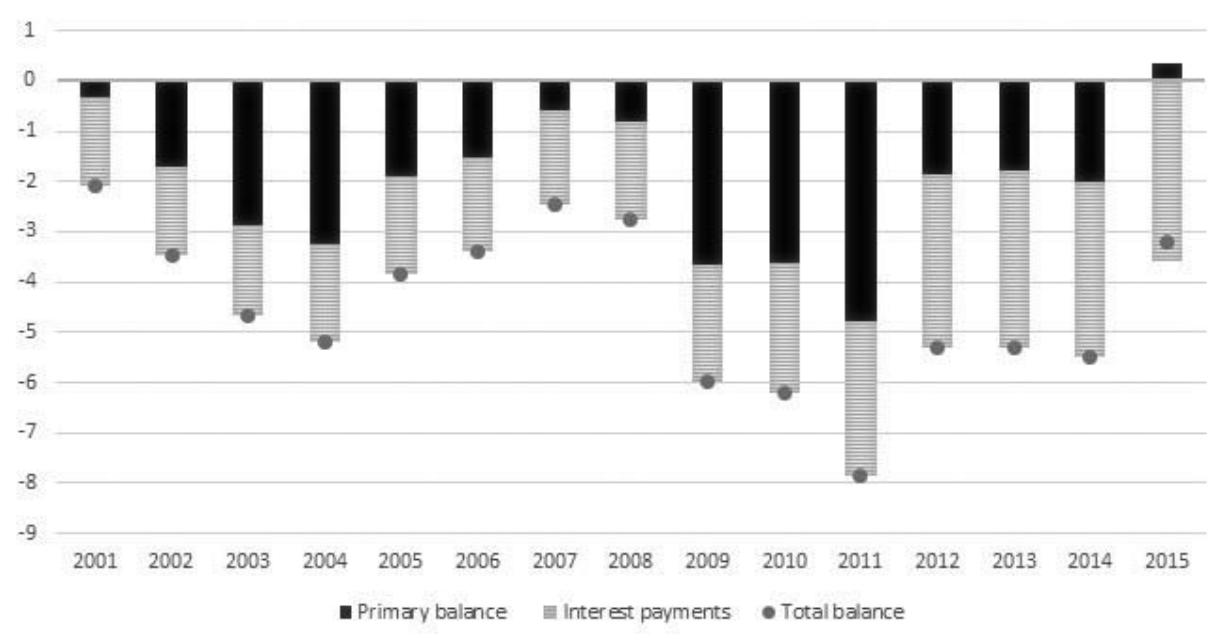

Figure 2. Total balance, primary balance and interest payments ( $\%$ of GDP)

Source: AMECO (2016).

Simple "eyeball metrics" suggest that the period of public debt unsustainability occurs parallel with the economic crisis. The earlier analysis based on annual data suggests that in 2009 major disruption occurs in fiscal stance and fiscal sustainability. Looking at quarterly data, the last quarter of 2008 can be observed as the main breakpoint in the public debt trajectory. However, for the purpose of empirical research and in order to make this analysis more robust, a formal and empirical analysis of breakpoints in the public debt trajectory is conducted.

The common approach in the breakpoint literature is to describe a trajectory of the variable of interest as an AR(1) process so as a starting point we define the following regression:

$$
d_{t}=c+\beta d_{t-1}+\varepsilon_{t}
$$

where $c$ is a constant, $d_{t}$ is a debt-to-GDP ratio and $\varepsilon_{t}$ is an error term.

Based on the estimation of this regression, two multiple break tests are used: (i) Quandt-Andrews and (ii) Bai-Perron test. The results of these tests are presented in Appendix (Tables A.1 and A.2). The results are in line with the before mentioned assumption as both tests indicate the last quarter of 2008 as the formal breakpoint in the public debt trajectory. Interestingly, the Bai-Perron test indicates two more breaks, first in 2011:Q2, when public debt in Croatia officially broke the $60 \%$ of GDP benchmark and 2013:Q4, when we could see a gradual deceleration of the rising debt-to-GDP ratio. However, in the rest of the analysis we will mainly focus on 2008:Q4 as the most important breakpoint date. 


\section{METHODOLOGY}

\subsection{Switching regression approach}

As stated previously, 2008:Q4 can be seen as a (negative) turning point in the Croatian economy. After 2008:Q4, dynamics of the economic and the fiscal system substantially changed. The GDP growth rate decreased from an average $4.3 \%$ in 2001-2008 to an average $-1.6 \%$ in 2009-2015. The debt-to-GDP ratio increased from an average $38.6 \%$ of GDP in 2001-2008 to an average $71.2 \%$ of GDP in 2009-2015. By simply looking at the data it is visible that Croatia went through two different economic regimes. Thus, to formally test this assumption and to see whether the regime changes have an effect on the effectiveness of fiscal policy, a regime-switching regression approach is used.

The switching model assumes that there is a different regression model associated with each regime. Given regressors $X_{t}$ and $Z_{t}$, the conditional mean of dependent variable $y_{t}$ in regime $m$ is assumed to be linear:

$$
\mu_{t}(m)=X_{t}{ }^{\prime} \beta_{m}+Z_{t}{ }^{\prime} \gamma
$$

where $\beta_{m}$ and $\gamma$ are vectors of coefficients. Note that the $\beta_{m}$ coefficients for $X_{t}$ are indexed by regime and that the $\gamma$ coefficients associated with $Z_{t}$ are regime invariant.

Lastly, it is assumed that the regression errors are normally distributed with variance that may depend on the regime. In that case the model is:

$$
y_{t}=\mu_{t}(m)+\sigma(m) \varepsilon_{t} .
$$

Our baseline model is defined as follows:

$$
\dot{y}_{t}=\beta_{0}+\beta_{1} \dot{g}_{t}+\beta_{2} \dot{d}_{t}+\beta_{3} \dot{f}_{t}+y_{i-1}+\varepsilon_{t}
$$

where $y_{t}, g_{t}, d_{t}$ and $f_{t}$ represent annual change in real GDP, government consumption, debt-to-GDP ratio and foreign demand ${ }^{3}$, respectively, while $y_{t-1}$ is a lagged dependent variable (to avoid the autocorrelation problem). Such structure of the model allows us to analyse the effects of fiscal policy and debt-to-GDP ratio directly on the growth figure, but also to assess the interconnection among fiscal spending and debt.

Foreign demand is introduced as an important control variable as Croatia is a small open economy with high level of synchronisation of the business cycle with the Eurozone. 


\subsection{SVAR approach}

To analyse the effects of fiscal policy on the economic activity the structural VAR (SVAR) model is used. Blanchard - Perotti (2002) identification method is often used as a benchmark for such analyses. The SVAR approach predicts that a positive spending shock (deficit financed i.e. leaving taxes unchanged) has a positive effect on output. ${ }^{4}$ The original Blanchard - Perotti model (1999) takes only three variables: government spending, net taxes and real GDP, which is often called a closed model. Depending on the structural characteristics of a given economy, the model can be extended by introducing the variables that present different determinants which can affect the fiscal policy effectiveness (trade openness, labor market rigidness, exchange rate regime, level of public debt, etc.). ${ }^{5}$

The analysis starts with a three-variable (closed) model:

$$
X_{t}=\alpha+\sum_{i=1}^{p} A_{i} X_{t-i}+D_{t}+I_{t}+u_{t} .
$$

Following the Blanchard - Perotti (2002) vector $X_{t}=\left[T_{t}, G_{t}, D D_{t}\right]$ ' includes deflated and seasonally adjusted log-values of net indirect tax revenue $\left(T_{t}\right)$, total general government spending $\left(G_{t}\right)$ and domestic demand $\left(D D_{t}\right)$. The exogenous variables included in the model are constant $(\alpha)$, the time trend $\left(I_{t}\right)$ and a dummy variable $\left(D_{t}\right)$, which represents the structural breakpoint of fiscal unsustainability and takes a value of 1 in 2008:Q4. Vector $I_{t}$ includes the long-term trends of corresponding variables. ${ }^{6}$ Finally, vector $u_{t}=[\mathrm{t}, \mathrm{g}, \mathrm{dd}]$ represents the vector of innovations of the reduced model (RF), $u_{t} \sim\left(0, \sum_{\mathrm{u}}\right)$. The time lags are set according to AIC and SIC criteria. In the second step, the mentioned closed model is extended by including the fourth endogenous variable (public debt) in model (5). The identification scheme follows Blanchard - Perotti (2002) ap-

4 Also, a positive tax shock (leaving government spending unaffected) has a negative effect on output.

$5 \quad$ For example, Ravn - Spange (2012) extended the model for Denmark by introducing variables that represent external (foreign) demand shocks. Similar was done for Croatia by DeskarŠkrbić et al. (2014).

6 It is assumed that the long term trends of corresponding variables have no influence on the long term trends of other variables. This assumption is compatible with the view that fiscal policy has no long run effects on the economy. The focus of this analysis is on the effectiveness of public spending in steering short term fluctuations. To capture the effects of this cyclical interdependence between fiscal shocks and economic activity, we use HP filter to de-trend all the variables and proceed our analysis on the cyclical components of all variables (see more Deskar-Škrbić - Šimović 2017). 
proach for the closed model and Deskar-Škrbić - Šimović (2017) approach for the extended model ${ }^{7}$.

\subsection{Data}

For the empirical part of the paper, as well as for the empirical identification of the breakpoints and the regime changes, quarterly data is used for the same period as in the previous analysis (2001:Q1-2015:Q4). The sources for all variables used in the empirical part are Eurostat (National accounts, ESA 2010) and/or AMECO (2016).

\section{RESULTS AND DISCUSSION}

The regime switching regression results are presented in Table 1. According to the results, the model recognises two regimes, coinciding with the change in the mean of the dependent variable between 2001-2008 and 2009-2015.

In the first regime the effect of changes in government spending on economic growth was marginally negative but statistically insignificant. The changes in the debt indicator had a negative and statistically significant effect on the growth figure. In the second regime government spending became an important growth determinant, with statistically significant coefficient above 1 (approximation of the multiplier), in line with the theoretical and the empirical fact that fiscal policy (government expenditures) has a stronger effect on growth during recessions ( $\mathrm{Au}-$ erbach - Gorodinchenko 2012). The change in debt ratio remained statistically significant but its negative effect strengthened with the rise of instability. Thus, despite the fact that the fiscal spending effectiveness rises during recessions, related increase of the debt unsustainability mitigates the effects of anti-cyclical fiscal policy.

Figure 3 presents the impulse response functions based on the SVAR model presented previously. It can be seen that the effects of discretionary government

7 The model specification details are available in Deskar-Škrbić - Šimović (2017). Because of the listing length, stability, serial correlation, normality and heteroskedasticity tests are available upon request. For this kind of empirical researches, data limitations and relatively short time series are always limitations for econometric modelling. The results show that the recession caused by the global financial crisis in Croatia had long lasting consequences, which can also be associated with other elements that are unexplored in this paper. In further research topics, other determinants of fiscal policy i.e. control variables should be introduced, and the analysis should be extended for other EU and transition countries. 
Table 1. Results of the regime switching model

\begin{tabular}{lrrrr}
\hline Variable & Coefficient & Std. error & z-Statistic & Prob. \\
\hline Regime 1 & & & & \\
C & 0.002331 & 0.015496 & 0.150424 & 0.8804 \\
G & -0.014609 & 0.259704 & -0.441305 & 0.6590 \\
F & 1.741589 & 0.443133 & 3.930174 & 0.0001 \\
GDEBT & -0.212218 & 0.108420 & -1.957361 & 0.0503 \\
AR(1) & 0.353556 & 0.203918 & 1.733813 & 0.0830 \\
\hline Regime 2 & & & & \\
C & 0.011061 & 0.014346 & 0.771047 & 0.4407 \\
G & 1.085977 & 0.258152 & 4.206726 & 0.0000 \\
F & 1.183918 & 0.491312 & 2.409708 & 0.0160 \\
GDEBT & -0.357553 & 0.110556 & -3.234143 & 0.0012 \\
AR(1) & 0.904157 & 0.240194 & 3.764281 & 0.0002 \\
\hline
\end{tabular}

Source: Author's calculations.

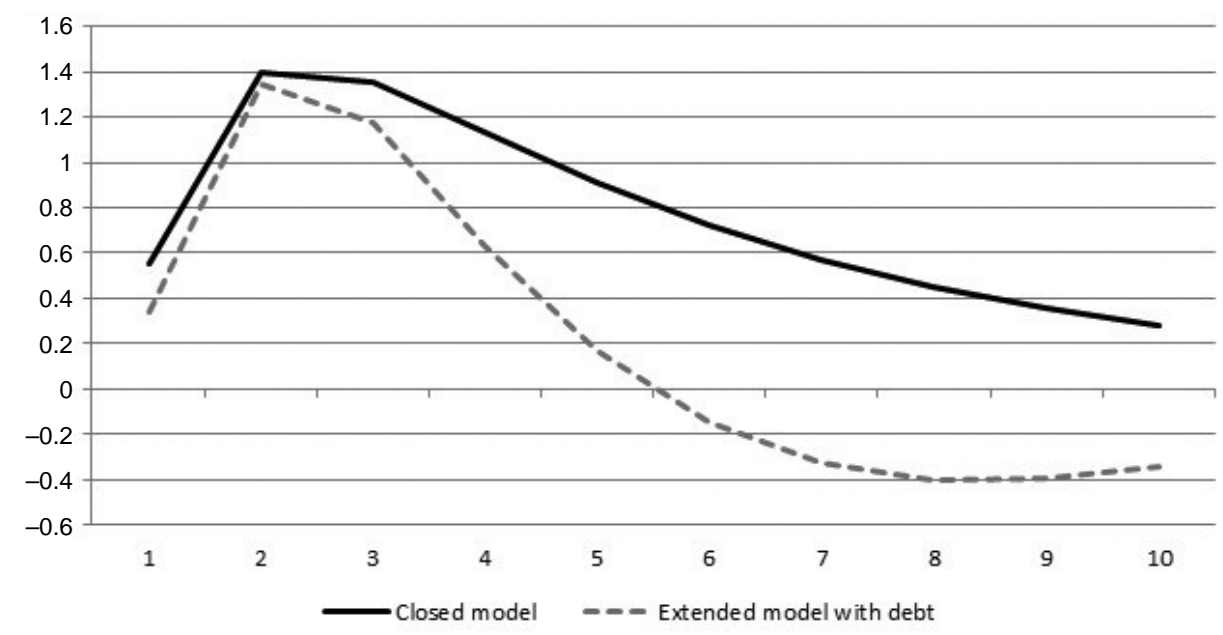

Figure 3. Impulse responses

Source: Author's calculations.

spending shock in the closed model is positive and statistically significant in the first eight quarters after the shock.

In the extended model with the debt-to-GDP indicators, fiscal shocks have a positive but milder statistically significant effect on economic growth in the second and the third quarter, while this effect turns to be negative and statistically 
Table 2. Multiplier effects of structural fiscal spending shock on domestic demand

\begin{tabular}{lcc}
\hline & Closed model & Extended model with public debt \\
\hline 4th quarter & 1.14 & 0.63 \\
8th quarter & 0.45 & -0.40 \\
\hline
\end{tabular}

Note: The effects are statistically significant.

Source: Author's calculations.

significant in the eighth quarter. To get a clearer view on the size of the fiscal impact on economic growth, in Table 2 we present the IRF coefficients (fiscal multipliers) in the first and the second year after the shock.

According to the results, in the first year after the shock the fiscal impact in the closed model is almost twice the size of the fiscal impact in the extended model with public debt. In the second year the first model indicates milder, but positive multipliers, while the second model shows negative multipliers. Based on the impulse response analysis, it seems that public debt posts limitations to the effectiveness of fiscal spending in Croatia.

\section{CONCLUSION}

The period 2001-2015 in Croatia was followed by changes in regimes regarding the public debt level and the fiscal policy influence. Growing public debt and fiscal unsteadiness were progressing from the last quarter of 2008, due to the beginning of a long economic and financial crisis. By the end of 2015 the level of public debt was $86.7 \%$ of GDP, which was significantly higher than the Maastricht criteria of $60 \%$ of GDP. The analysis of the public debt sustainability in Croatia has shown that public debt was mainly sustainable until 2008 , i.e. unsustainable after 2009 with an exemption of 2015. The analysis of the sustainability indicators and literature review has shown that total budget deficit, primary deficit and real interest rates are still too high and that there is still a great difference between the achieved and the stabilising levels. Therefore, further fiscal efforts are required in order to reach sustainable levels and to stabilise the public debt. It can be concluded that the fiscal unsustainability, i.e. the growth of public debt was equally influenced by negative economic trends and the lack of fiscal adjustment, as it was by worsening in financing terms and the increase of interest rates in the period of recession.

The empirical results confirm the thesis that public debt level significantly affects and reduces the effectiveness of fiscal policy. The regime switching model proved the importance of public debt in both regimes, despite the fact that the effectiveness of fiscal spending rises during recessions, and the related increase of 
debt unsustainability mitigates the effects of possible anti-cyclical fiscal policy. The extended SVAR model with public debt, compared to the closed economy model, clearly proved reducing impact on the size of fiscal multipliers, making them even negative after 5 quarters.

\section{REFERENCES}

Afonso, A. - Sousa, R. M. (2009): The Macroeconomic Effects of Fiscal Policy. ECB Working Paper Series, No. 991.

Aizenman, J. M. - Hutchison, Y. - Jinjarak, Y. (2013): What Is the Risk of European Sovereign Debt Defaults? Fiscal Space, CDS Spreads and Market Pricing of Risk. Journal of International Money and Finance, 34(C): 37-59.

AMECO (2016): Annual Macro-Economic Database (AMECO). European Commission, Directorate General for Economic and Financial Affairs.

Arghyrou, M. - Kontonikas, A. (2012): The EMU Sovereign-Debt Crisis: Fundamentals, Expectations and Contagion. Journal of International Financial Markets, Institutions and Money, 22(4): 658-677.

Auerbach, J. A. - Gorodnichenko, Y. (2012): Measuring the Output Responses to Fiscal Policy. American Economic Journal: Economic Policy, 4(2): 1-27.

Babić, A. - Krznar, I. - Nestić, D. - Švaljek, S. (2003): Dinamička analiza održivosti javnog i vanjskog duga Hrvatske (Dynamic Analysis of Croatia's Fiscal and External). Privredna kretanja $i$ ekonomska politika, 13(97): 77-126.

Bajo, A. - Primorac, M. (2013): The Cost of Government Borrowing and Yields on Croatian Government Bonds. Newsletter, No. 83. Institute of Public Finance, Zagreb. http://www.ijf.hr/upload/files/file/ENG/newsletter/83.pdf

Batini, N. - Eyraud, L. - Forni, L. - Weber, A. (2014): Fiscal Multipliers: Size, Determinants, and Use in Macroeconomic Projections. IMF Technical Notes and Manuals, No. 04.

Blanchard, O. - Perotti, R. (2002): An Empirical Characterization of the Dynamic Effects of Changes in Government Spending and Taxes on Output. The Quarterly Journal of Economics, 117(4): 1329-1368.

Contreras Banco, J. - Battelle, H. (2014): Fiscal Multipliers in a Panel of Countries. Banco de México Working Papers, No. 15.

Cota, B. - Žigman, A. (2011): The Impact of Fiscal Policy on Government Bond Spreads in Emerging Markets. Financial Theory and Practice, 35(4): 385-412.

Deskar-Škrbić, M. - Šimović, H. (2017): Effectiveness of Fiscal Spending in Croatia, Slovenia and Serbia: The Role of Trade Openness and Public Debt Level. Post-Communist Economies, 29(3): 336-358.

Deskar-Škrbić, M. - Šimović, H. - Ćorić, T. (2014): The Effects of Fiscal Policy in a Small Open Transition Economy: The Case of Croatia. Acta Oeconomica, 64(S1): 133-152.

Eurostat (2017): National Accounts (ESA 2010).

Hory, M. P. (2016): Fiscal Multipliers in Emerging Market Economies: Can We Learn Something from Advanced Economies Experiences. International Economics, 146: 59-84.

Ilzetzki, E. - Mendoza, E. - Végh, Cs. (2013): How Big (Small?) are Fiscal Multipliers? Journal of Monetary Economics, 60(2): 239-254.

Krznar, I. (2002): Analiza održivosti fiskalne politike u RH (Analysis of the Sustainability of Fiscal Policy in the Republic of Croatia). Financijska teorija i praksa, 26(4): 813-835. 
Mihaljek, D. (2003): Analiza održivosti javnog i vanjskog duga Hrvatske pomoću standardnih financijskih pokazatelja (Analysis of Public and External Debt Sustainability for Croatia: Application of Standard Financial Indicators). Privredna kretanja i ekonomska politika, 13(97): 29-75.

Mihaljek, D. (2009): The Global Financial Crisis and Fiscal Policy in Central and Eastern Europe: The 2009 Croatian Budget Odyssey. Financial Theory and Practice, 33(3): 239-272.

Ravn, S. H. - Spange, M. (2012): The Effects of Fiscal Policy in a Small Open Economy with a Fixed Exchange Rate: The Case of Denmark. Working Papers, No. 80. Danmarsk Nationalbank.

Šimović, H. - Batur, A. (2017): Fiskalna održivost i održivost javnog duga u Hrvatskoj (Fiscal Sustainability and Public Debt Sustainability in Croatia). In: Blažić, H. - Dimitrić, M. - Pečarić, M. (eds): Financije na prekretnici: Imamo li snage za iskorak? (Finance at Turning Point: Do We Have Strength Stepping out?) Rijeka: Ekonomski fakultet, pp. 271-287.

Šimović, H. - Ćorić, T. - Deskar-Škrbić, M. (2014): Mogućnosti i ograničenja fiskalne politike u Hrvatskoj (Possibilities and Limitations of Fiscal Policy in Croatia). Ekonomski pregled, 65(6): $541-575$.

Sopek, P. (2010): Budget Deficit and Public Debt in Croatia. Newsletter, No. 49. Institute of Public Finance, Zagreb. http://www.ijf.hr/eng/newsletter/49.pdf

Sopek, P. (2011): Testing the Sustainability of the Croatian Public Debt with Dynamic Models. Financial Theory \& Practice, 35(4): 413-442.

Švaljek, S. (1997): Granice javnog duga: pregled teorije i metoda ocjene održivosti politike zaduživanja (Public Debt Boundaries: Theory Review and Sustainability Assessments Methods of Public Debt Policy). Privredna kretanja i ekonomska politika, 7(61): 34-65. 


\section{APPENDIX}

\section{RESULTS OF BREAKPOINT TESTS}

Table A.1 Quandt-Andrews test

\begin{tabular}{lcc}
\hline Statistic & Value & Prob. \\
\hline Maximum LR F-statistic (2008Q4) & 16.90209 & $\mathbf{0 . 0 0 0 0}$ \\
Maximum Wald F-statistic (2008Q4) & 33.80417 & $\mathbf{0 . 0 0 0 0}$ \\
\hline
\end{tabular}

Source: Author's calculations.

Table A.2 Bai-Perron test

\begin{tabular}{lccccc}
\hline \multicolumn{2}{l}{ Schwarz criterion selected breaks: } & 2 & & & \\
\multicolumn{2}{l}{ LWZ criterion selected breaks: } & 1 & & & \\
\hline \multirow{2}{*}{ Breaks } & \# of Coefs. & $\begin{array}{c}\text { Sum of Sq. } \\
\text { Resids. }\end{array}$ & Log-L & $\begin{array}{c}\text { Schwarz* } \\
\text { Criterion }\end{array}$ & $\begin{array}{c}\text { LWZ* } \\
\text { Criterion }\end{array}$ \\
0 & 2 & 126.2874 & -100.9004 & 0.976948 & 1.068870 \\
1 & 5 & 75.94741 & -86.91609 & 0.687011 & 0.919523 \\
2 & 8 & 59.53235 & -80.21925 & 0.662071 & 1.038780 \\
3 & 11 & 52.98193 & -77.01361 & 0.764084 & 1.289071 \\
\hline
\end{tabular}

Estimated break dates:

1: 2008Q4

2: 2008Q4, 2013Q4

3: 2008Q4, 2011Q2, 2013Q4

Note: * Minimum information criterion values are displayed with shading.

Source: Author's calculations. 